\title{
Adrian Wilson's Printing for Theater
}

\author{
W. THOMAS TAYLOR
}

This article presents the text of a talk given by $W$. Thomas Taylor on November 17, 1989, to celebrate the addition of Adrian Wilson's Printing for Theater as the three millionth volume acquired by The University of Iowa Libraries. - Editor.

I have been trying for some time to recall the first time I met Adrian Wilson. Strangely enough, I can't seem to do it. I suspect this may be the result of having documented so much of Adrian's life in books I have published that the whole of his career seems somehow part of mine, entwined for so long that the ends of the threads can no longer be found. I cherish certain memories: working at a sunny breakfast table with Adrian and Joyce on the bibliography of his work; long cheerful walks and dinners in their North Beach neighborhood; and especially Adrian's instruction in the gentle art of mixing martinis, a drink much favored by printers, no doubt because the smell and taste remind us of the powerful solvents used in the pressroom. If the beginning of the thread is lost in Bay fogs and gin mists, the other end is somewhere in the future, and I'm not sure I even want to find it. I enjoy Adrian's continuing presence in our office as we work on a volume of his letters, written to his parents during the Second World War. Adrian was a conscientious objector. He dug ditches at a C.O. camp in North Dakota, served as a guinea pig at a hospital in Minnesota, and fought forest fires on the West Coast. He ended up in the C.O. camp at Waldport, Oregon, which was designated as a camp for people interested in pursuing the fine arts in their spare time. It was a fertile environment, where Adrian encountered and embraced the two loves of his life: his wife, Joyce, and his mistress, typography. Fortunately, Joyce did not complain about this arrangement; indeed, she got to know the mistress rather well herself.

After the war Adrian and Joyce, along with a number of others from the Waldport camp, moved south to San Francisco. If you were young, idealistic, and energetic, it was a wonderful 
place to be in 1946. Theater, music, and poetry were all flourishing and were an intimate part of the new couple's life. They were founders of the Interplayers, a theater group which survived for almost twenty years; Adrian was a fine clarinetist, and played with, among others, Weldon Kees, who besides being a pianist was a remarkable poet. In 1954 Adrian printed and published a volume of Kees' poetry; six years later, Kim Merker published Kees' Collected Poems here in Iowa City. There are many threads.

But back to Adrian and his mistress. Thanks to Adrian's letters to his parents, we can pinpoint the date they took up with each other, after two years of flirtation. It was 10 June 1947. He wrote: "After running in the harness of several dumb jobs during the winter; ...I have begun my own printing business. Of course it means that I work twice as hard and long as I would for someone else and that I dream type all night, but I can't wait to get to the press in the morning." However, by year's end reality had subdued romance, and in a letter of 13 December 1947 Adrian utters a lament that will be all too familiar to anyone who has tried to earn a living by printing: "It has been like living in a vise these last few months. I marvel at the way I am able to work 16 hours a day, rushing between the typesetters, the paper company, the shop and Berkeley, but somehow I seem to be always behind, and always broke." In January 1948 he was trying to find work, applying without success at the Grabhorn Press and Jack Stauffacher's Greenwood Press. But he was far from despair; he wrote: "I certainly have faith in the richness which life can hold; at the moment I look for it most in the area of work. As my leaving school to print on my own indicates, I believe discovery in work comes through independent search. It is really a sort of relief that no one would give me a job again this week. I am forced to make all the decisions and to do the job the best I possibly can because it is all mine. Dreams of losing my position are something I'll stay clear of. What I might fear is not being able to do a job with more originality and craftsmanship than 
anyone else could do it. If I have decided to be a printer I must certainly be the greatest printer ever."

This was a heady ambition, possible only for a young printer who had not yet seen a Gutenberg Bible. In a world predicated upon continual improvement, it is sobering to realize that the very first printed book may still lay legitimate claim to being the greatest. But if Adrian never became the greatest of all printers, I think that his work might make a claim more modest, but nonetheless distinguished: He was among the most original and inventive printers of this century. And he was very much a printer of this century, and no other. His work does not look back; it lives in the present, deriving its energy from an imagination nurtured on James Joyce, D.H. Lawrence, Frank Lloyd Wright, and Igor Stravinsky. Feeling his way on his own in late 1948 he said he wanted to make "large, open, modern pages." A mere nine years later, in 1957, he culminated this process of exploration with his masterpiece, Printing for Theater, which you have selected to be the three millionth volume for this library.

The astonishing quality of this book was not entirely unexpected-in 1953, for instance, seven of the fifty books in the Rounce \& Coffin Club's prestigious Western Books Exhibition were designed by Adrian-but it is nonetheless in a class by itself. I have never been able to improve upon David Glixon's remarks when he selected it as the outstanding book among the Fifty Books of the Year Exhibition chosen by the American Institute of Graphic Arts for 1957: "In both design and production, Printing for Theater is a work of art. While its great size is functional, permitting the inclusion of a score of tipped-in theater programs, this volume would retain most of its beauty even if you cut the format by a third, printed its 64 pages in just two colors on less costly stock than handmade Tovil, and bound it in standard cloth instead of in handwoven Belgian linen... His brilliant use of Stempel's Tajanus display type with Caslon Old Style text, his unconventional spacing, his impish yet purposeful disposition of illustrations - they all help to add an authentic and exciting masterpiece to the roster of American books." 


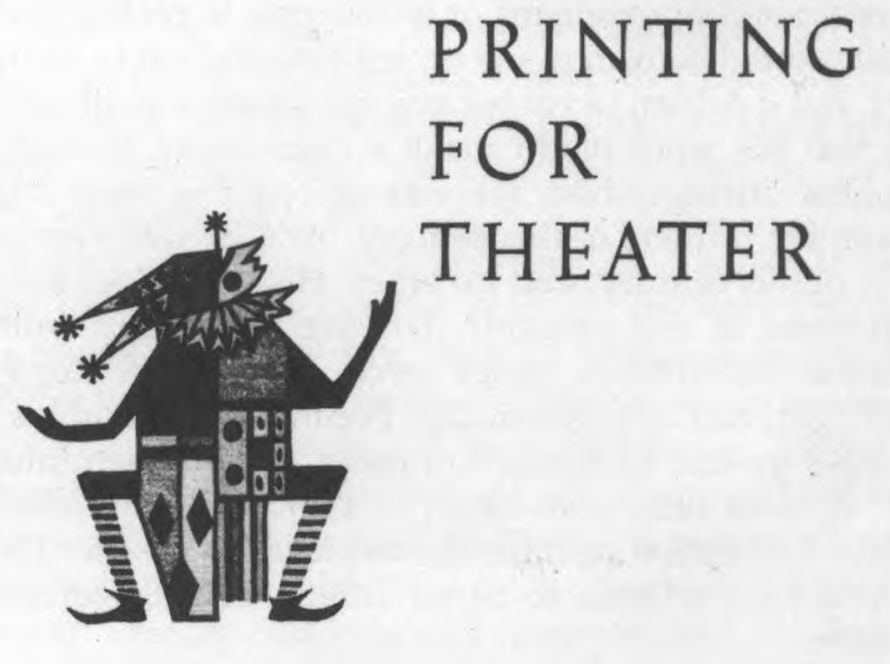

B Y

ADRIAN WILSON

SAN FRANCISCO: 1957 
At a distance of thirty-five years, it becomes more clear just how significant this book was to the development of a modern style in American bookmaking. To be sure, there had been earlier ventures - the work of W.A. Dwiggins and the Cummington Press come to mind-but Printing for Theater was on a different scale. Large and imposing, it could confront the masterworks of the English private press movement-the stately books of the Kelmscott, Ashendene, and Doves tradition-and speak to them in a different voice, yet as an equal. It is made with the finest of traditional materials -English handmade paper and handset foundry type-and is printed with impeccable craftsmanship. Yet it is light and graceful and spirited in a way that most English books simply are not. It is a great book: a great modern book, a great American book.

However, as the exhibit in your library amply demonstrates, Printing for Theater was but one book among nearly two hundred that Adrian designed or printed during his lifetime. What distinguishes this large body of work is the breadth of spirit which could apply the same standard of imagination and technique to a corporate report printed by four-color process in an edition of thousands, as to a privately printed book of poetry, printed letterpress on handmade paper in an edition of 150. It is too often assumed in the world of "fine" books that this is simply not possible; that there is something inherent in the processes of modern technology that render it sterile. Perhaps the most articulate exponent of this view was Eric Gill. He wrote in 1930:

There are, then, two typographies ... and apart from God or profits, the test of one is mechanical perfection, and of the other sanctity - the commercial article at its best is simply physically serviceable and may per accidens, be beautiful in its efficiency; the work of art at its best is beautiful in its substance and per accidens, is serviceable as an article of commerce.

That sanctity of purpose can redeem indifferent mechanical technique is clear-the books of Hilary Pepler's St. Dominic's Press, equally notable for bad presswork and enduring loveliness, are a humbling example. But is it possible that another 
proposition is also true? That mechanical perfection in an article of commerce can be redeemed by the sanctity of its maker? Is it possible that we in the world of "fine" bookmaking have established a self-serving and self-fulfilling dichotomy between modern technology and worthwhile values?

I think this may be so, and I also think that Adrian Wilson's books stand as evidence that this need not be the case. The very environment in which he worked demonstrated the equilibrium that he was able to maintain between the new and the old, the rapid and the deliberate, the commercial and the private. His studio had a front room filled with drafting tables, cluttered with blue lines, photographs, T-squares, and a computer; the back room contained an imposing black Heidelberg cylinder letterpress, and walls lined with typecases filled with German and Dutch foundry type. There are any number of his books that combine computer-generated text type with handset foundry display type; they co-exist in harmony because Adrian brought the same imagination, energy, and care to the one as he did to the other. For instance, with a commission in hand to do the Fireman's Fund's 101st Annual Report, how does he respond? He calls Ansel Adams "out of the blue" and gets four magnificent photographs as illustrations. And confronted with 491 photographs of cities to be turned into a book of 225 pages on urban planning, a prospect that would immediately send me to the aforementioned bottle of gin, what does he say? He calls it "one of my favorite design experiences," and remarks that "the subject and the people I worked with were delightful."

I think you will see the delight that Adrian took in his work reflected strongly from the pages of almost every book in this exhibition. Looking at them, you might try forgetting for a moment all you know about type, paper, and printing, and concentrate instead on an image of their designer: a large man with a gentle voice, kind but with courage behind his convictions. A good fellow who loved the theater, played jazz and classical music on his clarinet with equal skill and pleasure, who enjoyed the ancient cities of Europe and the modern buzz 
of North Beach. A man who was deeply modest, yet had a sure sense of his gifts, who laughed a lot, and mixed a wicked martini. Perhaps, in the end, you may discover that it is not the kind of type that determines the character of a book, but rather the type of man or woman who made it. I don't know, at a Center for the Book, how you go about teaching that; but in your library, in the example of Adrian Wilson's work and play, you can certainly demonstrate its enduring results. 